\title{
sciendo
}

Transport and Telecommunication, 2020, volume 21, no. 3, 211-220

Transport and Telecommunication Institute, Lomonosova 1, Riga, LV-1019, Latvia

DOI 10.2478/ttj-2020-0017

\section{EUROPEAN REGIONAL AIRPORT: FACTORS INFLUENCING EFFICENCY}

\author{
Allan Nõmmik ${ }^{1,3}$, Dago Antov ${ }^{2,3}$ \\ ${ }^{1}$ Estonian Aviation Academy, Lennu 40, Reola \\ Kambja Parish, Tartu County 61707, Estonia \\ allan.nommik@eava.ee \\ ${ }^{2}$ Tallinn University of Technology, Smart City Center of Excellence (Finest Twins) \\ Akadeemia 15A, Tallinn, 19086, Estonia \\ ${ }^{3}$ Tallinn University of Technology, Department of Mechanical and Industrial Engineering \\ Akadeemia 15A, Tallinn, 19086, Estonia
}

\begin{abstract}
During the recent decade a lot of research has been focused on identification of the importance of regional airport for the local economy and the measuring and predicting of the airport's efficiency. With regard to individual airport planning it turns out that airports are not free in the optimization of infrastructure due the need to comply international aviation standards and recommended practices, one the one hand, and the tendency of air transportation system development including aircraft design and airlines' fleet development, on the other. Furthermore, it is also important to take into account the specificity of each particular airport, including the traffic variability resulting from seasonality, with the airport's mission geared to it. We found, that one of the reasons for the relatively low efficiency of regional airports, given the general trend in the growth in the number of seats for narrowbody aircraft. Likewise, it has been found, that the seasonality of air traffic at regional airports is comparatively high. In addition, this paper spotlights the ways the theoretical model of returns to scale affects the efficiency of the apron of the regional airport and briefly discusses the different interpretations of the definition of regional airport.
\end{abstract}

Keywords: regional airport, airport efficiency, air traffic variability, regional aircraft

\section{Introduction}

The airports that were once constructed, sometimes in pursuit of objectives other than those of civil aviation, will eventually be facing the necessity of infrastructure renovation or complete reconstruction. This may arise from the need of increasing their capacity or efficiency, in order to bring airport infrastructure into line with the main focus of airport operations, on the one hand, and from the need of infrastructure renovation, on the other. For example, the International Civil Aviation Organization, hereafter ICAO, (2013) provides a range of depreciation periods, as follows: 15-30 years for runway, taxiways, aircraft stands and 20-40 years for buildings.

The lack of ability of regional airports to cover their operating expenses and invest in development has become general knowledge, reflected also in European Union legislation. The regulation 2014/C 99/03 "Guidelines on State Aid to Airports and Airlines" links the annual passenger turnover of airports with their ability to cover the costs of operation and, also, with their investment potential. At the same time, this document sets limits on state aid in the same areas. With this in mind, the importance of airport efficiency indicators such as input for airport infrastructure and operation planning become crucial.

A number of research works have been completed focusing on measuring and predicting of airports' operational and financial efficiency. For example, Gutiérrez and Lozano (2016) have provided a long list of literature on the inputs and outputs of airports' efficiency analysis. Pavlyuk (2012) gave an extensive review of research papers on this topic by calling attention to airports' spatial competition as a factor affecting efficiency. However, applied research shows, that irrespective of the ownership of airports, public or privatized, small airports have "very low efficiency levels" (Olariaga, Moreno, 2019).

Nowadays, there are many instruments available for airport planning, including simulation with the capabilities of modern software that enables the optimization of an individual airport infrastructure and operations based on forecasts. The data related to individual airport capacity and operational planning could be used as indicators on some extent but they do not reflect the real choices that the airport faces. However, for resolving the issues, it is important to know the demand characteristics. On the other hand, it is important to take into account the forecasts and aircraft size - the criteria emanating, which coming from the mission of airport and the potential aircraft for operating (De Barros and Wirasinghe, 1997). 
The objective of this research is to examine the regional airports' efficiency from three perspectives. First, to consider the possibilities of optimizing the airfield according to international aviation standards and recommended practices on the one hand, and the trends in aircraft design, on the other. Second, based on benchmarking, to determine the variability of air traffic due to seasonal effects that arise from the regional airport's business missions in transporting passengers by air. Third, based on airport infrastructure and operational planning, to suggest other features that illustrate how the airport size can impact its efficiency.

\section{Methodology}

\subsection{Regional airport definition}

To make the research unequivocal, it is necessary to define the concept of regional airport. In various sources, instead of or in addition to the term regional airport, other terms are used as well. Table 1 below provides the varying explanations given to those different concepts or terms.

Besides, the Airport Council International, hereafter ACI, (2010) divides regional airports into two groups: regional with annual passenger turnover more than 5 million and those that are small regional airport with annual passenger turnover below 5 million.

By using those varying terms while referring to regional airport in this study, the authors mean by 'regional airport' non-hub airports that have relatively small traffic of commercial air transportation, that may be located, but need not necessarily be, far from large centres of agglomeration or hub-airports. The authors do not bind the constraints at the choice of airport to its role in the air transport system, whether it is oriented to feeder lines or not, but takes into account the airport's business mission.

Table 1. List of airport's definitions for resulting categorization of regional airport

\begin{tabular}{|l|l|l|}
\hline Concept & Main characteristics & Sources \\
\hline Periphery & $\begin{array}{l}\text { Located far from large centres of agglomeration, using with } \\
\text { "remote"/ the opposite of the core airport/ smaller competitors for } \\
\text { nearby hub airports }\end{array}$ & $\begin{array}{l}\text { Tavalaei, M. M., Santalo, J. (2019); } \\
\text { Bloice, L. at al. (2017). }\end{array}$ \\
\hline Small & $\begin{array}{l}\text { By some criteria smaller than others, } \\
\text { airports with low volume of traffic }\end{array}$ & $\begin{array}{l}\text { Adler, N., at al (2013); Červinka, M. } \\
\text { (2017); Jimenez, E. at al. (2017) }\end{array}$ \\
\hline Secondary & $\begin{array}{l}\text { Non non-main airport or non-hub airport - the opposite of the main } \\
\text { airports, oriented for servicing the own catchment area }\end{array}$ & $\begin{array}{l}\text { Červinka, M. (2017); Dziedzic, M., } \\
\text { Warnock-Smith, D. (2016) }\end{array}$ \\
\hline Remote & $\begin{array}{l}\text { Airport's location isolated from more populated areas by distances } \\
\text { or/and lack of transport connections }\end{array}$ & $\begin{array}{l}\text { Donehue, P, Baker, D (2012); Bloice, } \\
\text { L. at al. (2017). }\end{array}$ \\
\hline Rural & Airports oriented to servicing of general aviation & Donehue, P, Baker, D (2012) \\
\hline Domestic & $\begin{array}{l}\text { US airports which are providing only domestic flights; for the EU } \\
\text { old definition which arises from regulated market environment }\end{array}$ & FAA (2018) \\
\hline Destination & $\begin{array}{l}\text { Airports using the business model as a service centre for the local } \\
\text { community, with no or minimal transfer traffic }\end{array}$ & ACI (2010) \\
\hline Feeder & $\begin{array}{l}\text { Basically the same as destination airport, mainly servicing the } \\
\text { feeder flights, as a "spoke in hub and spoke system" }\end{array}$ & Postorino (2010) \\
\hline
\end{tabular}

Activities by which the regional airports can improve their efficiency indicators and increase aeronautical and non-aeronautical revenues are several. These include focusing on air freight, aircraft Maintenance, Repair \& Overhaul (MRO) and manufacturing, training flights and wider cooperation with general aviation sector, servicing of business flights, support of military or search and rescue operations, etc. However, the main parameter for the evaluation of airport ability to cover its operating costs and investments in the airport infrastructure also comprised the number of passengers served.

Though some airports that serve more than 1 million passengers, can cover from their revenue all or large parts of their operating costs, this study focuses on airports with more than 200,000 passengers yet less than one million passengers per year (European Commission, 2014; Pashkevich et al., 2017). Combining the two above-mentioned factors, this study focuses on those airports, which are facing difficult financial conditions, but have a significant volume of commercial traffic. In addition, we are taking into account the airports servicing 1-3 million passengers per year while also being oriented to service the low cost airlines (LCC) and, by this, have already increased their catchment area with using “airport leakage" effect (Suzuki et al., 2003). 


\subsection{Comparing aircraft development trends with ICAO recommended practice}

The methodology of airport design starts from defining of the mission of the airport including challenges (Medvedev et al. 2017). Decision about the aircraft size for which the airport is planned will be made, pursuant to (1) the mission of the airport and (2) the trends in the development of airlines' fleets. In this study, we focus on the tasks for passenger transport and the trends in aircraft design that have an impact on regional airport planning those airports can perform.

From the point of view of servicing the air transport passengers, regional airports have to fulfil the following main tasks:

a) Ensure catchment area accessibility and population's mobility by serving regular flights including taking advantage of the market situation by servicing low cost carrier (LCC) flights.

b) Secure the population's living standards; serve seasonal, regular and charter flights to the leisure destinations;

c) Serve leisure flights if the economy of airport's catchment area is oriented towards servicing incoming tourism.

There are numerous aircraft-related parameters used for airport categorization, one of which is the reference code, which is partly derived from the aircraft wingspan (see Table 2). The reference code is the basis for airport infrastructure planning, e.g., for minimal distance between centre line of runway and taxi ways and for clearance distances between aircraft stands on the apron (ICAO, 2018).

Table 2. Aerodrome reference code (ICAO 2018)

\begin{tabular}{|c|l|l|l|}
\hline $\begin{array}{l}\text { Aerodrome code } \\
\text { (number) }\end{array}$ & \multicolumn{1}{|c|}{ Reference field length (m) } & $\begin{array}{l}\text { Aerodrome } \\
\text { code (letter) }\end{array}$ & Wingspan (m) \\
\hline 1 & Less than 800 & A & Up to but not including 15 \\
\hline 2 & 800 up to but not including 1 800 & B & 15 up to but not including 24 \\
\hline 3 & 1200 up to but not including 1 800 & C & 24 up to but not including 36 \\
\hline 4 & $1800 \mathrm{~m}$ and over & D & 36 up to but not including 52 \\
\hline & & E & 52 up to but not including 65 \\
\hline & & F & 65 up to but not including 80 \\
\hline
\end{tabular}

The earlier, letter part of reference code is also influenced by another factor such as aircraft outer main gear wheel span (OMGWS), which since 2018 is a separate parameter for airport infrastructure planning. Nonetheless, an aircraft parameter such as wing span is still playing an important role in aerodrome planning. We have to mention that the type of aircraft plays a greater role in planning the airport infrastructure and operations. For example, the aircraft classification number (ACN) is also important to consider when planning the runway pavement, or the equipment and resources to be implemented, so that they comply with the rescue and firefighting category which conforms to the operating aircraft overall length and maximum fuselage width (ICAO, 2018).

\subsection{Regional airports' efficiency}

Airports are not decision makers, regards airline operations. The general decisions for opening the routes, timetable, usage aircraft - are traditionally made by airlines or, in the case of charters or Public Service Obligation (PSO) services, by a legal entity ordering flights.

We emphasize that it is not possible to change the infrastructure quickly, as it, in turn, will also requires large resources that the regional airport may not usually have. Pursuant to the aims set for this study, we are focusing on the operating efficiency as it concerns infrastructure planning. Pavlyuk (2012) has highlighted the airport efficiency by using the indicators of airport partial factor productivity (PFP), which are ratios "of a chosen airport output to a given resource used" and divided into the following groups of indexes: labour, infrastructure, financial performance. The same author (Pavlyuk, 2015) presents a list of inputs and outputs used in 96 studies on airports' PFPs. The outputs are mainly representing the air passenger movements (APM) and the number of air traffic movements (ATM). In order to avoid emergence of confusion in the usage of the terms, as ATM is widely used in aviation as an acronym for "air traffic management", the acronym TM (traffic movements) is used in this paper. The inputs most frequently used to measure the airport's infrastructure efficiency, include:

(a) Number of runways, runway length or area.

(b) Aircraft stands (number or area).

(c) Terminal area. 
The runway parameters are set according to the aircraft types that will start operating at the given airport, and therefore the specific aircraft types should be considered for operation. According to "Airplane Characteristics for Airport Planning" (Boeing, 2013), the required runway length depends on:

(a) Aerodrome elevation and meteorological conditions of operations.

(b) Aircraft type incl. configuration.

(c) Payload and flight range.

Here it shall be mentioned that the length of the runway has limited possibilities for optimizing for efficiency terms. Attempts to reduce this may result in operating restrictions, thus affecting the attractiveness of the airport as a destination for the aircraft operator, or just make the operation impossible from the point of view of flight safety. However, if one airport is located on higher altitude than the other or is subject to adverse meteorological conditions, the runway dimensions may be even larger to ensure the operation of the same aircraft in the same configuration, regardless of the size of the airport. For the analysis, it is important to include the appropriate TM. In addition to commercial aviation, regional airports can serve general aviation by providing facilities for training flights or state aviation structures' operations. As an outcome, the number of training flights may account for a higher runway efficiency, even though the operation of light aircraft requires much smaller runway than that of the airport. The maximum runway capacity depends on different circumstances incl. configuration of taxiways and air traffic control procedures. The total capacity of a single runway, depending on the airport and the proportion of take-offs may exceed 40 TM per hour (Janic, 2000).

As general, the aircraft parking stands refer to the airport's ability to support the traffic of a given airport. But, in that case, the dimensions of the operating aircraft must be taken into account. However, if the airport's secondary activities are airfreight, flight training, MRO or parking for leasing companies, then tying TM and APM is questionable. An inadequate assessment can be made not only of the aircraft stands' dimensions but also of the intensity of use.

Applied research (Nõmmik and Antov, 2017) shows the possibilities of modelling a regional airport by focusing on the departing passengers' behavior and the airport terminal bottlenecks capacity. Also, it is possible to optimize apron capacity (Mircovic and Tosic, 2017), once it has been decided, which aircraft types and how are going to use the airport. Individual airport planning needs to be guided by the airport mission, including the information about or from specific consumers.

\subsection{Regional airport traffic variability}

Each development plan designed, drawing on the results of forecasts. Forecasts are generally prepared on the annual basis. However, on the other side, the demand has its own characteristics. For a single airport, taking into account the annual numbers only are not sufficient for airport infrastructure and operation planning. It is necessary, with regard to regional airports or airports of limited capacity that the changes in traffic demand during the year are taken into account. It is possible to find a solution, e.g. a regional airport with limited traffic, based on the cost/benefit analysis. There are several options available for an individual airport, for optimising the labour or financial productivity but this should always reflect solely the results of extensive research. These options include:

(a) Various airport services may be at the expense of airport staff, but the services may be also outsourced.

(b) Technological solutions that correspond to the status of the airport, including passenger traffic, the level of wages in the country, and other factors that influence the decisions on the implementation of technological solutions. It is also important to consider the local legislation, for example, whether it is possible passenger boarding without their identification at the gate.

(c) Where several regional airports are managed by a single organization, movements of equipment and personnel between airports may be possible, as appropriate.

In order to predict the variability of traffic, it is useful to use benchmarking by taking into account the airports that perform a similar mission. For the investigated airports, this indicator may be vague due to the variability of air traffic resulting from a significant change in demand during the year. Tsekeris (2011) in own research found the significance of seasonality in demand on the airports' performance. This is especially important because some previous studies contain a result as airports that serve more APM and TM are more effective (Psaraki-Kalouptsidi and Kalakou, 2011) or a statement that "seasonal concentration is higher at smaller versus larger airports" (Halpern, 2011). Proceeding from this, yet taking into account the objectives of the research, we are interested in the finding the maximum of seasonality index for airports capacity and operation planning. 


\section{Analysis}

Based on the objectives of this research and the synthesis of the methodological material offered, the following features have been identified for the regional airport, as they play a critical role in terms of infrastructure and operational planning:

(a) The runway size or size of aircraft stands cannot be always optimized by taking into account the needs of efficiency. That is why the runway efficiency measures indicator TM per runway, which could be replaced for one runway airport with TM, has also limited value for benchmark. It can be considered as an indicator that provides input for planning taxiway(s) configuration in order to minimize construction and operational costs. It can also serve as an indicator of the need to find secondary activities for the airport.

(b) When selecting data for benchmarking, the mission of the airport, which is close to the type of the planned airport, should be precisely defined. Analyzing a particular airport, it is necessary to consider its specific users.

(c) Based on the goals of our research, we are interested in the seasonality of air traffic, as well as in other possible reasons for the low efficiency of regional airports.

\subsection{Narrow body aircraft development trend}

Considering the importance of aircraft wing span for planning the airport infrastructure, we took into account all the narrow-body aircrafts that have been produced or entered into production during the last decade.

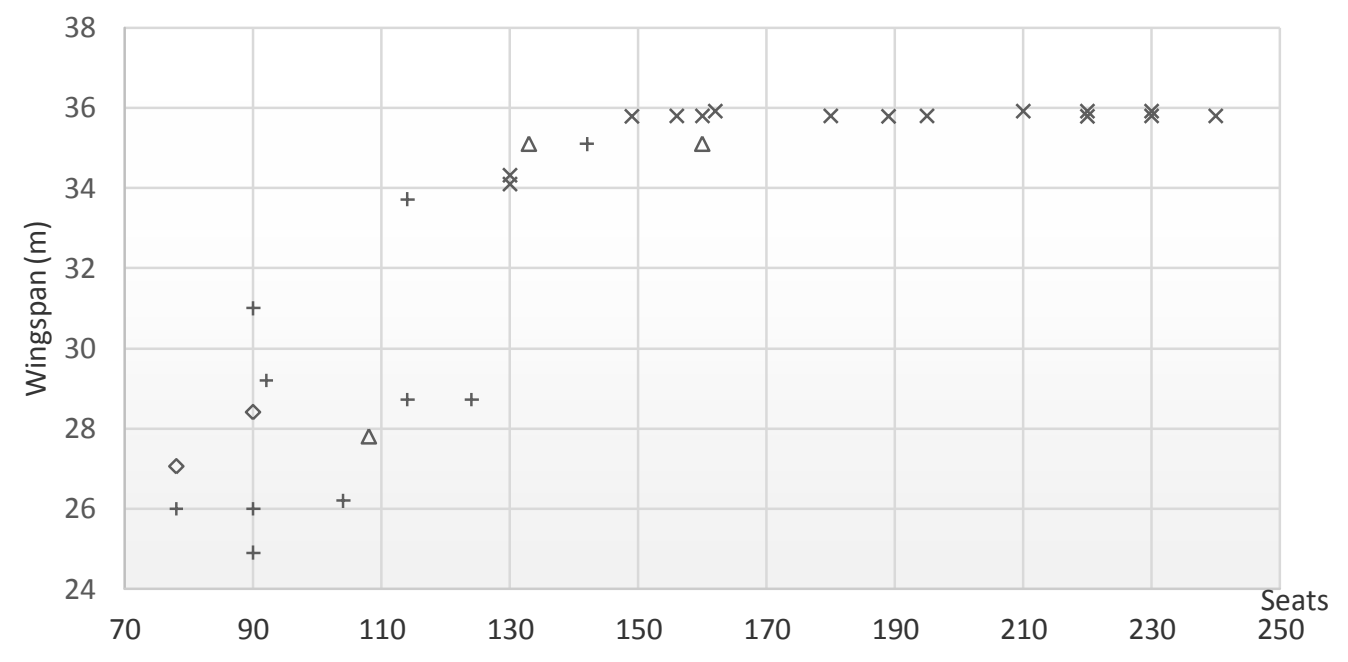

$\times-6$ abreast seating aircraft; $\Delta-5$ abreast seating aircraft; +-4 abreast seating jet aircraft; $\diamond-4$ abreast seating turboprop aircraft

Figure 1. Aircraft wingspan by maximum number of seats

Figure 1 shows the data of the narrow-body aircraft with the maximum seating capacity exceeding 70. The figure reflects current decade in production aircraft or planned for the next few years as follows: 6-abreast seating Airbus 320 series, Boeing 737 including NG and MAX series; 5-abreast seating A220 family and SSJ100; 4-abreast seating Bombardier CRJ 700/900/1000; Embraer E and E2 series; MRJ70/90 family aircraft. It also includes the data of Dash-400 and ATR-72 4-abreast seating turboprop aircraft. The data used is issued by the aircraft manufacturers. It is obvious that $36 \mathrm{~m}$ is an important limit for airplane design, which allows airplanes to use the airport reference code for planning according to the $\mathrm{C}$ reference number (see the Table 2). This conclusion can be drawn from 5-abreast and 6-abreast aircraft data with a maximum seat numbers from 135 to 240 .

\subsection{Regional airport traffic variability}

For a regional airport benchmarking, it is important to select suitable objects. In practice, sometimes one carefully selected example is enough for comparison. To ensure the diversity of this study we analyzed five airports' business profiles and 25 regional airports, with five airports per each airport group (see Table 3). For comparison, we included the sixth group with five large airports into the analysis. 
Table 3. Airports according to their profile in 2016

\begin{tabular}{|c|c|c|c|c|}
\hline Airport type & Airport (Country of location) & $\mathbf{A P M}$ & TM & $\begin{array}{l}\text { Av. TM per } \\
\text { day }\end{array}$ \\
\hline \multirow[t]{5}{*}{ Remote } & Bornholm (Denmark) & 268481 & 5411 & 15 \\
\hline & Kirkenes Høybuktmoen (Norway) & 306031 & 6337 & 17 \\
\hline & Visby (Sweden) & 463972 & 9057 & 25 \\
\hline & Skellefteå (Sweden) & 281187 & 3024 & 8 \\
\hline & Kuopio (Finland) & 226872 & 4013 & 11 \\
\hline \multirow[t]{5}{*}{ Tourism } & Zadar (Croatia) & 501816 & 5303 & 15 \\
\hline & Kittilä (Finland) & 257213 & 2456 & 7 \\
\hline & Almería (Spain) & 908929 & 9214 & 25 \\
\hline & Toulon-Hyères (France) & 497948 & 7803 & 21 \\
\hline & Preveza/Aktion (Greece) & 482116 & 4406 & 12 \\
\hline \multirow{5}{*}{$\begin{array}{l}\text { Without } \\
\text { LCC }\end{array}$} & Vaasa (Finland) & 288384 & 5668 & 16 \\
\hline & Linz (Austria) & 431649 & 6045 & 17 \\
\hline & Ronneby (Sweden) & 231860 & 4204 & 12 \\
\hline & Kristiansund/Kvernberget (Norway) & 250328 & 5597 & 15 \\
\hline & Saarbruecken (Germany) & 398860 & 6429 & 18 \\
\hline \multirow{5}{*}{$\begin{array}{l}\text { With } \\
\text { LCC }\end{array}$} & Limoges-Bellegarde (France) & 290308 & 4208 & 12 \\
\hline & Kaunas (Lithuania) & 740499 & 4600 & 13 \\
\hline & Szczecin (Poland) & 459142 & 4262 & 12 \\
\hline & Ostrava (Czech Republic) & 236794 & 6596 & 18 \\
\hline & Percara Abruzzo (Italy) & 569315 & 5084 & 14 \\
\hline \multirow{5}{*}{$\begin{array}{l}\mathrm{AL} \\
\text { with } \\
\mathrm{LCC}\end{array}$} & Skavsta (Sweden) & 2025019 & 13102 & 36 \\
\hline & Girona (Spain) & 1646736 & 10314 & 28 \\
\hline & Niederrhein/Weeze (Germany) & 1853346 & 11453 & 31 \\
\hline & Bratislava (Slovakia) & 1745967 & 14816 & 41 \\
\hline & Frankfurt-Hahn (Germany ) & 2514919 & 16718 & 46 \\
\hline \multirow[t]{5}{*}{ Large airports } & Stockholm Arlanda (Sweden) & 24696871 & 220168 & 603 \\
\hline & Barcelona (Spain) & 43749730 & 290639 & 796 \\
\hline & Amsterdam (Netherlands) & 63549632 & 466845 & 1279 \\
\hline & Vienna (Austria) & 23318172 & 219550 & 602 \\
\hline & Frankfurt/Main (Germany) & 60668733 & 434810 & 1191 \\
\hline
\end{tabular}

The groups are derived based on the airport activity profile as follows:

Group 1 'Remote': operations in the remote areas. The airports with location far from more highly populated areas have been included in this research.

Group 2 'Tourism': operation with strong tourism orientation.

Group 3 'Without LCC': operation without LCCs. The airports are operating without LCC carriers while servicing schedule and charter flights.

Group 4 'With LCC': operation with LCCs. These airports servicing traditional and low cost carriers.

Group 5 'AL with LCC': specialization for low cost carriers with increasing the catchment area at the expense of a larger airport in the neighborhoods. Owing to the growth of the catchment area with using "airport leakage" effect, the fifth group includes airports with an exceptional passenger turnover of more than 1 million but less than 3 million passengers per year in the category.

Group 6 'Large airports': is a control group of the busiest airports in Europe with different volumes of annual traffic. An additional selection criterion was the presence of a potential competitor in the $5^{\text {th }}$ group.

Proceeding from the objective of the study, we are interested in the maximum values of variability. The data is retrieved from Eurostat (Statistical Office of the European Community) database, under the category "Air passenger transport by main airports in each reporting country" (avia_paoa). For the analysis we used statistics of the operational years 2012-2017. The characteristics of the airports include "passengers carried" as APM indicator and "commercial passenger air flights" as a TM indicator. For each selected airport, in each observed year, the months with the highest traffic variability were selected. Next, the maximum value relative to the annual average were calculated to find the index of variability. Thereafter, for every airport the average MAX values for six years were found and the standard deviations $(\sigma)$ were calculated. The results are presented in Table 4. Note the higher seasonality at regional airports compared with the 6th group - the large airports. Nor did we find a significant role of LCC in reducing seasonality at regional airports.

Explanation of the reasons of the relatively high standard deviations at regional airports may be an object of further research if it is needed for benchmarking. For example, the high scores of the standard deviation at Kaunas airport can be explained by extraordinary traffic numbers during the closure for reconstruction of the Vilnius Airport in its neighbourhood in the summer of 2017 (Lithuanian Airports, 2018). 
Table 4. Variability of traffic in the selected airports

\begin{tabular}{|c|c|c|c|c|c|}
\hline $\begin{array}{l}\text { Airport } \\
\text { type }\end{array}$ & Airport (Country of location) & MAX (APM) & $\sigma$ & MAX (TM) & $\sigma$ \\
\hline \multirow[t]{5}{*}{ Remote } & Bornholm (Denmark) & 1,35 & 0,12 & 1,21 & 0,09 \\
\hline & Kirkenes Høybuktmoen (Norway) & 1,22 & 0,02 & 1,07 & 0,01 \\
\hline & Visby (Sweden) & 1,93 & 0,12 & 1,52 & 0,25 \\
\hline & Skellefteå (Sweden) & 1,22 & 0,05 & 1,21 & 0,03 \\
\hline & Kuopio (Finland) & 1,26 & 0,05 & 1,24 & 0,08 \\
\hline \multirow[t]{5}{*}{ Tourism } & Zadar (Croatia) & 2,44 & 0,07 & 2,46 & 0,21 \\
\hline & Kittilä (Finland) & 3,24 & 0,31 & 2,02 & 0,10 \\
\hline & Almería (Spain) & 1,60 & 0,07 & 1,36 & 0,09 \\
\hline & Toulon-Hyères (France) & 1,55 & 0,08 & 1,83 & 0,06 \\
\hline & Preveza/Aktion (Greece) & 2,86 & 0,12 & 2,89 & 0,19 \\
\hline \multirow{5}{*}{$\begin{array}{l}\text { Without } \\
\text { LCC }\end{array}$} & Vaasa (Finland) & 1,27 & 0,03 & 1,21 & 0,05 \\
\hline & Linz (Austria) & 1,49 & 0,11 & 1,28 & 0,03 \\
\hline & Ronneby (Sweden) & 1,23 & 0,02 & 1,22 & 0,03 \\
\hline & Kristiansund/Kvernberget (Norway) & 1,16 & 0,03 & 1,10 & 0,06 \\
\hline & Saarbruecken (Germany) & 1,47 & 0,19 & 1,27 & 0,07 \\
\hline \multirow{5}{*}{$\begin{array}{l}\text { With } \\
\text { LCC }\end{array}$} & Limoges-Bellegarde (France) & 1,30 & 0.05 & 1,17 & 0,05 \\
\hline & Kaunas (Lithuania) & 1,48 & 0,45 & 1,40 & 0,68 \\
\hline & Szczecin (Poland) & 1,44 & 0,21 & 1,31 & 0,29 \\
\hline & Ostrava (Czech Republic) & 2,27 & 0,13 & 1,94 & 0,08 \\
\hline & Percara Abruzzo (Italy) & 1,31 & 0,06 & 1,33 & 0,07 \\
\hline \multirow{5}{*}{$\begin{array}{l}\text { AL } \\
\text { with } \\
\text { LCC }\end{array}$} & Skavsta (Sweden) & 1,41 & 0,02 & 1,24 & 0,03 \\
\hline & Girona (Spain) & 1,79 & 0,06 & 1,68 & 0,12 \\
\hline & Niederrhein/Weeze (Germany) & 1,39 & 0,06 & 1,29 & 0,05 \\
\hline & Bratislava (Slovakia) & 1,95 & 0,13 & 1,63 & 0,08 \\
\hline & Frankfurt-Hahn (Germany) & 1,33 & 0,08 & 1,22 & 0,04 \\
\hline \multirow{5}{*}{$\begin{array}{l}\text { Large } \\
\text { airports }\end{array}$} & Stockholm Arlanda (Sweden) & 1,15 & 0,02 & 1,13 & 0,03 \\
\hline & Barcelona (Spain) & 1,31 & 0,03 & 1,21 & 0,02 \\
\hline & Amsterdam (Netherlands) & 1,22 & 0,02 & 1,14 & 0,01 \\
\hline & Vienna (Austria) & 1,22 & 0,03 & 1,13 & 0,02 \\
\hline & Frankfurt/Main (Germany) & 1,22 & 0,02 & 1,10 & 0.01 \\
\hline
\end{tabular}

\subsection{Regional airport efficiency and traffic characteristics}

As mentioned above, we found out that aircraft stands can be considered standard, designed for aircraft that meet the reference code $\mathrm{C}$. The capacity of even one runway significantly exceeds the number of commercial flights at regional airports. Let us consider how the size of the airport, or rather the number of aircraft parking stands, can affect the efficiency from the point of view of the returns to scale in regional airport. The aircraft turnaround time or time while the stand is occupied by aircraft has been suggested by us as $t=40$ minutes, which can be considered significantly longer than the time it takes for the aircraft to occupy the runway for landing or take off. In our model, the "arrival times of aircraft" does not depend on the airport and can, thus, be considered a random value. In keeping with the above mentioned, we adduce the apron as Erlang multi-channel queuing system where $n$ is the number of channels by which we mean aircraft stands. Based on the underload of the runway as an ineffectively used resource on the one hand, as well as the small opportunity to influence the arrival time of the aircraft on the other, the regional airport apron should correspond to the maximum probability of aircraft reception. In order to ensure uninterrupted reception of aircraft, we do not take into account the possibility of a queue and are guided only by the probability of aircraft serving $p$ which should be maximized as $p \geq 0.995$. The goal is to find out with the condition described in equation (1), how many flights $T M_{f},\left(T M_{f}=\mathrm{TM} / 2\right)$ an airport can serve, dependent on the number of aircraft stands, under the conditions necessary to ensure minimal probability of blocking. In this model, the airport's operating time $T$ is 18 hours (from 6 a.m. to 24 p.m.).

$$
p \geq 1-\frac{\rho^{n}}{n !} p_{0}
$$

for what:

$p_{0}=\frac{1}{\Sigma \frac{\rho^{n}}{n !}}$, where: $p_{0}-$ the probability that the channel is free, or a fraction of the idle time of the channels, utilization factor $\rho=\frac{\lambda}{\mu}$, arrival rate $\lambda=\frac{T M_{f}}{T}, \mu-$ service rate $(\mu=1,5)$. To measure the efficiency, we used the formula (2) for calculating the potential channel utilization rate by service $(K)$. 


$$
K=\frac{\rho p}{n}
$$

The result of calculations is shown in Table 5. Based on the results it can be argued, that airport systems with a higher number of aircraft stands and more flights have obvious prerequisites for a higher apron efficiency.

Table 5. The impact of number of aircraft stands on the airport apron capacity and utilization

\begin{tabular}{|l|c|c|c|c|c|c|}
\hline Number of aircraft stands $(\mathbf{n})$ & $\mathbf{2}$ & $\mathbf{3}$ & $\mathbf{4}$ & $\mathbf{5}$ & $\mathbf{6}$ & $\mathbf{7}$ \\
\hline System capacity $\left(T M_{\boldsymbol{f}}\right)$ & 2 & 9 & 19 & 31 & 44 & 59 \\
\hline Utilization rate $(K)$ & 0,04 & 0,11 & 0,18 & 0,23 & 0,27 & 0,31 \\
\hline
\end{tabular}

In the case of the apron, we took into account the infrastructure only i.e. a place to stop the aircraft, which affects the indicators of congestion of aircraft stands and airport ground handling services. The infrastructure as well as the operation of the passenger terminal should be coordinated with the flow of aircraft arriving at the airport. However, the throughput capacity of critical service points such as check-in and security check, also provide space for passengers at different stages of servicing, directly depends on the number of passengers on the flight.

Table 6. European LCCs fleet development 2008 vs 2018 years

\begin{tabular}{|l|l|l|}
\hline Airline & $\begin{array}{l}\text { As of 2008 year fleet, aircraft type (number } \\
\text { of seats) }\end{array}$ & $\begin{array}{l}\text { As of 2018 new aircraft orders, aircraft type (number of } \\
\text { seats) }\end{array}$ \\
\hline RyanAir & Boeing B 737-800 (189) & Boeing B737 MAX-10 (up to 200) \\
\hline Easyjet & Airbus A319 (156) & Airbus A320NEO (186); A321NEO (235) \\
\hline Wizzair & Airbus A320 (180) & Airbus A321NEO (239) \\
\hline
\end{tabular}

With a decrease in the number of aircraft with fewer than 100 seats in Europe (Nõmmik, 2019), regional airports are faced with a situation where it is necessary to provide services to larger aircraft. Taking into account the fact that most regional airports have to be ready to serve LCC flights, we analyzed the changes in the fleets of these airlines in recent years. The results are presented in Table 6. The data is obtained from the websites of Europe's largest LCC airlines.

\section{Discussion and conclusions}

Modelling regional airports is generally simpler than that of large airports, but it requires consideration of their own specificities. It has been found that the wing span of nowadays narrow body aircraft in operation is close to the maximum value of the ICAO's reference code C. On one hand, it could be seen as flexibility. However, at the same time, it is a challenge and part of choices for the airport infrastructure, including terminal capacity planning. If the single regional airport is oriented, according to its business mission, to the activities, such as LCC services or holiday charters, it is reasonable to target at the longest versions of B737 or A320 aircraft families for infrastructure planning. Predictably, aviation standards and recommended practices, such as the reference code, will also be a constraint for aircraft designers, but this topic is beyond the scope of this research.

In the case of regional airports, when the size of the runway is often impossible to optimize in terms of increasing efficiency, one can just accept TM as a parameter for measuring the efficiency of using the runway. Based on the above-mentioned, we see a clear underload of runways at regional airports.

From the point of view of the efficiency of using the apron, a simplified model based on the theory of multichannel queuing, with no queue and minimal probability of failure, was presented. A relationship was shown between the number of aircraft stands and possible efficiency. However, this model shows only a predisposition to efficiency, which in practice needs to be realized. In the simplified model of the apron considered, the possible specific patterns of the distribution of arrivals of flights during the day, which may vary among airports, were not taken into account. However, it should be noted that the number of aircraft stands planned for servicing commercial flights should ensure the reception of aircraft arriving at night stop regardless of TM per day at the airport. With a small number of aircraft parked for night stop and their early departure, the ability of the apron to service flights under given condition can increase. A large number of aircraft at a night stop, whereby their number essentially determines the quantity of aircraft stands, will, besides the possible overload of the terminal due to tightly scheduled departures, also lead to apron inefficiency for a small number of flights during the day. 
Planning an airport solely on the basis of average values of traffic indicators cannot be considered substantial. This research confirmed also that regional airports expect relatively high traffic variability, which are dependent on the season. We have also noted that servicing LCC operators have not significantly reduced the variability in the chosen airport group, that is consistent with other research (Fernández et al., 2018). It can be explained by the fact that in this case LLC airlines often operate from regional airports as competitors for the seasonal charter market. The selection of regional airports for mission based groups can sometimes be considered rather conditional since the airports often perform several missions and the situation changes over time. Due to the wide representation of low cost carriers in regional airports we have also note that it has been difficulty to find suitable airports for building up a group "without LCC". It should also be noted that careful airport selection is essential for benchmarking, as it has been found that even at regional airports with the same profile, the variability of traffic is somewhat different.

\section{Acknowledgements}

This work has been supported by the European Commission through the H2020 project Finest twins (grant No. 856602).

\section{References}

1. Adler, N., Ülkü, T., Yazhemsky, E. (2013) Small regional airport sustainability: Lessons from benchmarking. Journal of Air Transport Management, 33, 22-31. DOI: 10.1016/j.jairtraman.2013.06.007.

2. ACI. (2010) An Outlook for Europe's Airports. Brussels: ACI Europe.

3. Boeing. (2013) 737 Airplane Characteristics for Airport Planning. Available on the internet: [https://www.boeing.com/resources/boeingdotcom/commercial/airports/acaps/737.pdf]

4. Bloice, L., Baxter, G., Gray, D. (2017) Report on the Social and Cultural Importance of Remote and Peripheral Airports. Deliverable 7.1, SPARA Project. 42 p.

5. Červinka, M. (2017) Small regional airport performance and Low cost carrier operations, Transportation Research Procedia, 28, pp. 51-58. DOI: 10.1016/j.trpro.2017.12.168.

6. De Barros, A., Wirasinghe, S.C. (1997) New aircraft characteristics related to airport planning. In: First ATRG Conference, June 25-27, Canada, Vancouver, pp 1-16.

7. Donehue, P., Baker, D. (2012) Remote, rural, and regional airports in Australia. Transport Policy. 24. 232-239. 10.1016/j.tranpol.2012.08.007.

8. Dziedzic, M., Warnock-Smith, D. (2016) The role of secondary airports for today's low-cost carrier business models: The European case. Research in Transportation Business \& Management, 21, 1932. DOI: 10.1016/j.rtbm.2016.07.002.

9. European Commission. (2014) Guidelines on State aid to airports and airlines. Official Journal of the European Union, C 99/03. Available on the internet: [ https://eur-lex.europa.eu/legalcontent/EN/TXT/?uri=CELEX\%3A52014XC0404\%2801\%29].

10. FAA. (2018) Airport Categories. Available on the internet: [https://www.faa.gov/airports/ planning_capacity/passenger_allcargo_stats/categories/].

11. Fernández, X. L., Coto-Millan, P., Diaz-Madina, B. (2018) The impact of tourism on airport efficiency: The Spanish case. Utilities Policy, 55, 52-58. DOI: 10.1016/j.jup.2018.09.002.

12. Gutiérrez, E. and Lozano, S. (2016). Efficiency assessment and output maximization possibilities of European small and medium sized airports. Research in Transportation Economics, 56, 3-14. DOI: 10.1016/j.retrec.2016.07.001.

13. Halpern, N. (2011) Measuring seasonal demand for Spanish airports: Implications for counterseasonal strategies. Research in Transportation Business \& Management, 1(1), August, 47-54. DOI: 10.1016/j.rtbm.2011.05.005.

14. ICAO. (2013) Airport Economics Manual, Doc 9562, Third Edition.

15. ICAO. (2018) Annex 14, Volume I, Aerodrome Design and Operations, Eighth Edition.

16. Janic, M. (2000) Air Transport System Analysis and Modelling. CRC Press.

17. Jimenez, E., Claro, J., de Sousa, J. P., de Neufville, R. (2017) Dynamic evolution of European airport systems in the context of Low-Cost Carriers growth. Journal of Air Transport Management, 64, 68-76. DOI: 10.1016/j.jairtraman.2017.06.027.

18. Lithuanian Airports. (2018) Lithuanian Airports finish a record-breaking summer season as number of passengers has grown by almost 50 percent. Available on the internet: 
[https://www.ltou.lt/en/media-1/news/lithuanian-airports-finish-a-record-breaking-summer-seasonas-number-of-passengers-has-grown-by-almost-50-percent].

19. Medvedev, A., Alomar, I., Augustyn, S. (2017) Innovation in airport design. Aviation, 21(1), 23-28. DOI: $10.3846 / 16487788.2017 .1303542$.

20. Mirkovic, B., Tosic, V. (2017) The difference between hub and non-hub airports - An airside capacity perspective. Journal of Air Transport Management, 62, 121-128. DOI: 10.1016/j.jairtraman.2017.03.013.

21. Nõmmik, A. and Antov, D. (2017) Modelling Regional Airport Terminal Capacity. In: 16th Conference on Reliability and Statistics in Transportation and Communication, RelStat'2016, 19-22 October, 2016, Riga, Latvia, Procedia Engineering, 178, 427-434. DOI: 10.1016/j.proeng.2017.01.083.

22. Nõmmik, A. (2019) Trends in development of aircraft for regional routes: impact on the european air transportation system. In: 13th Research and Education in Aircraft Design: Conference proceedings. 161-169. DOI: 10.13164/conf.read.2018.16.

23. Olariaga, O. D., Moreno, L. P. (2019) Measurement of airport efficiency. The case of Colombia. Transport and Telecommunication, 20(1), 40-51. DOI: 10.2478/ttj-2019-0004.

24. Pavlyuk, D. (2012) Airport benchmarking and spatial competition: a critical review. Transport and Telecommunication, 13(2), 123-137. DOI: 10.2478/v10244-012-0010-z.

25. Pavlyuk, D. (2015) Study of European airports' efficiency on the basis of multiple spatial stochastic frontier analysis. (Doctoral Thesis). Transport and Telecommunication Institute, Riga, Latvia. DOI: 10.13140/RG.2.2.26003.58408.

26. Pashkevich, A.; Nõmmik, A.; Antov, D. (2017) Competitiveness Analysis of Regional Airports Based on Location Planning Models: the Case Study of Finland. In: Proceedings of the 21st International Scientific Conference "Transport Means 2017", 754-761, Kaunas University of Technology.

27. Postorino M. N. (2010) Development of Regional Airports: Theoretical Analyses and Case Studies, First edition, Southampton, Boston: WIT Press.

28. Psaraki-Kalouptsidi, V., Kalakou, S. (2011) Assessment of efficiency of Greek airports, Journal of Airport Management, 5(2), 170-186.

29. Suzuki, Y., Crum, M. R. \& Audino, M. J. (2003) Airport choice, leakage, and experience in singleairport regions. Journal of Transportation Engineering, 129(2), 212-218. DOI: 10.1061/(ASCE)0733-947X(2003)129:2(212).

30. Tavalaei, M.M., Santalo, J. (2019) Pure versus hybrid competitive strategies in the airport industry. Transportation Research Part A: Policy and Practice, 124, 444-455. DOI: 10.1016/j.tra.2019.04.015.

31. Tsekeris, T. (2011) Greek airports: Efficiency measurement and analysis of determinants. Journal of Air Transport Management, 17(2), 140-142. DOI: 10.1016/j.jairtraman.2010.06.002. 